\title{
Response of Treatment in Patients with Primary Headaches and Hypertension: A Prospective Observational Pilot Study
}

\author{
Kan Basıncı Yüksekliğinin Eşlik Ettiği Primer Baş A ğrılı Hastalarda Tedaviye Yanıt: \\ Prospektif Gözlemsel Pilot Bir Çalışma
}

\author{
Abdullah Cüneyt Hocagil, (1) Hilal Hocagil, (D Volkan Ülker \\ Bulent Ecevit University Faculty of Medicine, Department of Emergency Medicine, Zonguldak, Turkey
}

\begin{abstract}
Objective: To determine the priority in the treatment of patients with primary headaches accompanied by high blood pressure. In our study, we investigated whether there was a relationship between the decline in headache after treatment and the change in the average arterial pressure.

Materials and Methods: This prospective observational study was performed with 101 patients who were admitted to the hospital emergency department with primary headache accompanied by high blood pressure. After treatment, the decrease in the severity of headaches, mean arterial pressure, and percentage value for the drop of mean arterial pressure were calculated for all patients.

Results: In the study, 25 (24.8\%) patients' headache decreased 3 levels, 43 (42.6\%) patients' headache decreased 2 levels, and 23 (22.8\%) patients' headache decreased one level. The mean arterial pressure value at admission was $118.58 \pm 12.65 \mathrm{mmHg}$, and after treatment at the $30^{\text {th }}$ minute decreased to $98.41 \pm 13.43$ $\mathrm{mmHg}$. Although there was a statistically significant $(\mathrm{p}<0.001)$ decrease in the mean arterial pressure value of patients with $2-3$ level decrease in the headache severity, there was no statistically significant $(\mathrm{p}>0.05)$ drop in the mean arterial pressure value of the patients with one level decrease in headache severity after treatment.
\end{abstract}

Conclusion: This study showed that when a primary headache, which is often associated with high blood pressure, was treated instead of treating high blood pressure as a secondary cause of headache, blood pressure decreased spontaneously.

Keywords: Emergency department, hypertension, primary headaches

\section{$\ddot{O} z$}

Amaç: Bu çalışmanın amacı, kan basıncı yüksekliğinin eşlik ettiği primer baş ağrılı hastalarda tedavi önceliğinin belirlenmesine katkıda bulunmaktır. Çalışmamızda baş ağrısına yönelik uygulanan tedavi sonrası baş ağrısındaki gerileme ile ortalama arteriyel basınçtaki değişim arasında ilişki olup olmadığını karşıllaştırdık.

Gereç ve Yöntem: Bu prospektif gözlemsel çalışma hipertansiyonun eşlik ettiği primer tip baş ağrısı şikayeti ile acil servise başvuran 101 hasta ile yapıldı. Tüm hastaların tedavi sonrası baş ağrılarındaki düşme düzeyleri, ortalama arteriyel basınç ve ortalama arteriyel basınçtaki düşme yüzdeleri hesaplandı.

Bulgular: Tedavi sonrası $25(\% 24,8)$ hastanın ağrısı 3 alt düzeye, $43(\% 42,6)$ hastanın ağrısı 2 alt düzeye, $23(\% 22,8)$ hastanın ağrısı 1 alt düzeye düşmüştü. Başvuru anında hastaların ortalama arteriyel basınç değerlerinin ortalaması 118,58 12,65 iken baş ağrısına yönelik tedavi sonrası 30 . dakikada hastaların ortalama arteriyel basınç değerlerinin ortalaması $98,41 \pm 13,43$ 'e gerilemişti. Baş ağrısına yönelik verilen tedavi sonrasında baş ağrısında değişme olmayan ve bir alt düzeye gerileyen hastaların ortalama arteriyel basınç oranında anlamlı düşme olmazken $(\mathrm{p}>0,05)$, baş a ̆ğısı iki ve üç alt düzeye gerileyen hastalarda ortalama arteriyel basınç oranlarında anlamlı düşme oldu $(\mathrm{p}<0,001)$.

Sonuç: Bu çalışma göstermiştir ki hipertansiyonla birlikteliği sık olan primer tip baş ağrılarında sekonder nedenler göz önünde bulundurularak yüksek kan basıncını kontrol etmeye yönelik tedaviler yerine baş ă̆rısı tedavi edilmelidir.

Anahtar Kelimeler: Acil bölümü, hipertansiyon, primer baş ağrısı

Address for Correspondence/Yazışma Adresi: Hilal Hocagil MD, Bulent Ecevit University Faculty of Medicine, Department of Emergency Medicine, Zonguldak, Turkey

Phone: +90 5053544434 E-mail: drhocagil@gmail.com ORCID ID: orcid.org/0000-0001-7314-752X

Received/Geliş Tarihi: 07.04.2017 Accepted/Kabul Tarihi: 25.08.2017

${ }^{\circ}$ Copyright 2018 by Turkish Neurological Society

Turkish Journal of Neurology published by Galenos Publishing House. 


\section{Introduction}

There is no consensus on the management of patients with high blood pressure (BP) and with no symptoms of acute target organ damage (TOD) (1). How to manage the patients admitted to the emergency deparment with headache and accompanying high BP is not exactly clarified (2). According to our clinical observations in cases where headache accompanied by high BP, it could be very difficult for physicians to understand what they are dealing with. It is not always possible to differentiate whether it is a headache because of high BP or it is high BP because of headache. Therefore, physicians may have doubts about which they should primarily treat. Headaches constitute an important portion of admissions to the emergency department and neurology clinics $(3,4)$. In the United States (US), approximately 3 million people (2-3\% of all emergency department presentations) are admitted to the emergency department due to headache every year (5). Headache, in which the clinical findings vary from 'very serious' to 'mild discomfort,' could be primary headache or a symptom caused by acute or chronic diseases (6). The majority of headaches encountered in emergency departments are primary headaches, which are classified as migraine, cluster-type, and tension-type. The severity of headaches in these patients generally decreases with symptomatic treatment (7). However, the pre- and post-treatment approach to headache requires a multifaceted perspective. Emergency department doctors should make the differential diagnosis between secondary headaches caused by structural and metabolic causes and primary headaches in which no cause and etiology is detected. This becomes more important, especially in the case of headaches accompanied by co-morbidities or a coincidental diseases (8). Hypertension (HT), as it is seen in one-third of the population of the US and one billion of the world population, is an important comorbid condition that may accompany migraine (9). There are difficulties in the management of patients with HT who account for up to $45 \%$ of emergency department presentations. In the emergency department, a sufficient consensus has not been provided for the management of patients with moderate HT [systolic blood pressure (SBP) $<180 \mathrm{mmHg}$, diastolic blood pressure (DBP) 90-120 mmHg] or with serious HT (SBP $>180 \mathrm{mmHg}$, DBP >120 $\mathrm{mmHg}$ ) without end organ damage $(10,11)$. For patients admitted to the emergency department with high $\mathrm{BP}$, there is insufficient evidence regarding the benefit or harm of reduction of high BP not accompanied with acute organ damage (1). However, it is known that ongoing HT changes the auto-regulation of cerebral perfusion. The reduction of $\mathrm{BP}$ more than $20-25 \%$ causes a disturbance in the auto-regulation and this in turn leads to a treatment-related decrease in cerebral perfusion and the development of various complications (7).

The purpose of this study was to contribute to the determination of the priority in the treatment of the patients with primary headaches accompanied by high BP. In our study, we investigated whether there was a relationship between a decline in headache after treatment and the change in the mean arterial pressure (MAP).

\section{Materials and Methods}

\section{Study Design and Subjects}

This prospective observational study was performed with 101 patients with primary headache accompanied by HT admitted to a second step city hospital emergency department, between May $5^{\text {th }}$, and July $31^{\text {st }}, 2013$ (Figure 1). The study was approved by the Dr. Lutfi Kirdar Kartal Training and Research Hospital of Local Ethics Committee (approval number: 8951337/1009/120).

\section{Study Criteria}

Inclusion criteria: Male and female patients aged over 18 years, who agreed to participate in the study, and who presented to the emergency department with symptoms of headache that were considered as primary-type headache accompanied with HT were included in our study. Consent forms were filled by all participants.

Exclusion criteria: Patients with evidence or suspicion of secondary headache conditions (trauma history, neurologic deficits, suspected intracranial infection, neck stiffness, suspected intracranial aneurysm, bleeding, surgical and tumor history, toxic exposures), patients with HT-associated TOD clinical and electrocardiologic findings (patients with clinical and electrocardiologic findings of HT-associated TOD), pregnancy or suspected pregnancy, patients with mental retardation or cognition

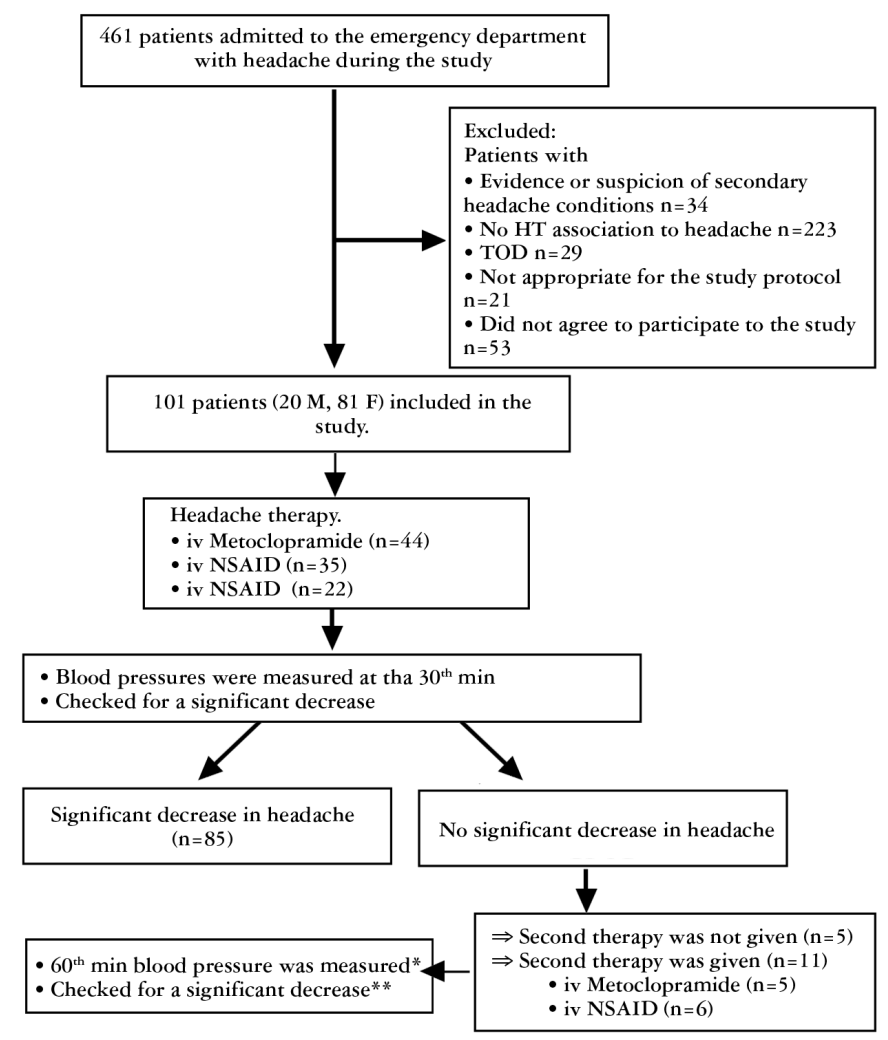

Figure 1. Study design and patient flow chart

*Intravenous vasodilator was given to one patient who had no decrease in blood pressure.

**No significant decrease was observed for one patient's headache. M: Male, F: Female, HT: Hypertension, TOD: Target organ damage, IV: Intravenous, IM: Intramuscular, NSAID: Non-steroidal anti-inflammatory drug 
impairment, allergies or adverse effect history for non-steroidal anti-inflammatory drug (NSAID) and metoclopramide, patients aged under 18 years, and those who did not agree to participate in the study were excluded from the study.

\section{Study Protocol}

Patients who presented to the emergency department with symptoms of headache and met the criteria for inclusion in the study were questioned for age, sex, and comorbid diseases (e.g., cerebrovascular disease, cardiovascular disease, HT, primary-type headache). Their headaches were evaluated in terms of duration, character, distribution, severity and associated symptoms, and data were recorded. The patients were questioned as to whether they had experienced a similar headache and if so what was their frequency. The severity of headache was classified into five categories based on a visual analog scale (VAS) (Figure 2). After resting for five minutes, all patients' right arm BPs were measured in the sitting position using a 13 x 47-cm cuff size manual BP measurement device (Erka, Perfect Aneroid Adult Sphygmomanometer, Germany). SBP $\geq 140 \mathrm{mmHg}$ or DBP $\geq 90$ $\mathrm{mmHg}$ values were considered as $\mathrm{HT}$. The patients with HT were further investigated to identify TOD by evaluating clinical findings, imaging, and laboratory values; if TOD was identified, patients were excluded from the study. Intravenous (IV) metoclopramide, NSAID (tenoxicam) and intramuscular (IM) diclofenac were administrated to the patients for the treatment of headache. IV treatments in $100 \mathrm{cc}$ saline solution were administrated over 15 minutes. Metoclopramide was preferred in patients with accompanying nausea. The administration type (IV or IM) of NSAID drug was left to the discretion of the patient. After the first treatment, the severity of headache as determined using the VAS scale and measured BP values were recorded at the $30^{\text {th }} \mathrm{min}$. After treatment, the decrease in the severity of headache, MAP, and the percentage value for the drop of MAP were calculated for all patients. After the first treatment, the second treatment (metoclopramide instead of NSAID, NSAID instead of metoclopramide) was administrated to 11 out of 16 patients whose headache did not adequately decline, the other 5 patients did not agree to the second treatment. The severity of

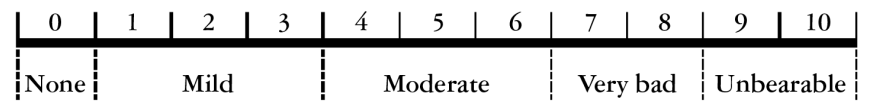

Figure 2. The headaches of the patients in the study group were classified into five groups according to a visual analog scale headache and BP values of these 16 patients were again recorded in the $60^{\text {th }}$ minute.

\section{Statistical Analysis}

All data was recorded on the SPSS 19.0 software (SPSS Inc., Chicago, IL, USA) and frequencies and descriptive statistics were calculated. The Wilcoxon signed-rank test was used to calculate the relationship between decline in the severity of headache and drop of MAP.

\section{Results}

A total 101 patients, $20(19.8 \%)$ males and $81(80.2 \%)$ females, were included in the study. The mean age of the patients was $55.55 \pm 12.94$ years (min: 22 max: 93 years). Of the patients, 6 $(5.9 \%)$ had cerebrovascular disease, $10(9.9 \%)$ had cardiovascular disease, 17 (16.8\%) had primary headache syndrome, $55(54.5 \%)$ had a history of HT. Thirty-nine $(38.6 \%)$ of the patients were admitted to the emergency department with headache lasting more than 12 hours, 19 (18.8\%) patients for 6-12 hours, 32 $(31.7 \%)$ for $2-6$ hours, and $11(10.9 \%)$ patients were admitted in the first 2 hours. During the patients' admission to the emergency department, the severity levels of headaches were classified as excruciating for $40(39.6 \%)$ patients, very bad for $42(41.6 \%)$ patients, and moderate for $19(18.8 \%)$ patients (Table 1$)$. Thirtyeight $(37.6 \%)$ patients described their headache as throbbing (pulsating), $26(25.7 \%)$ patients as pressing/tightening, and 23 $(22.8 \%)$ patients as a heaviness sensation in the head; the remainder described their headache in various ways. The pain localization for $35(34.7 \%)$ patients was defined as the neck, $21(20.8 \%)$ patients defined it as in both sides of the head, $11(10.9 \%)$ patients defined it as one side of the head, and $6(5.9 \%)$ patients defined it as both sides of the head and in the neck. The other 28 patients defined their pain locations as the forehead, localized in the retro-orbital area, orbital, periorbital and temporal areas, the top of the head or different combinations thereof. Although headaches were not accompanied by any symptoms in 22 patients (21.8\%), $22(21.8 \%)$ patients had nausea, $16(15.8 \%)$ patients had nausea, photophobia and phonophobia, and $10(9.9 \%)$ patients had symptoms such as restlessness and agitation accompanied by headache. The other 31 $(30.7 \%)$ patients had these symptoms separately or in different combinations.

IV metoclopramide treatment was given to $44(43.6 \%)$ patients, IV NSAID to $35(34.7 \%)$ patients, and IM NSAID to $22(21.8 \%)$ patients (Table 1$)$. Only one treatment was performed

Table 1 . The severity of headaches at admission and the treatment used

\begin{tabular}{|c|c|c|c|c|}
\hline \multirow[b]{3}{*}{ The severity of headache at admission } & \multicolumn{3}{|c|}{ The first therapy } & \multirow[b]{3}{*}{ Total (\%) } \\
\hline & IV Metoclopramide & IV NSAID & IM NSAID & \\
\hline & $\mathrm{n}(\%)$ & $\mathrm{n}(\%)$ & $\mathrm{n}(\%)$ & \\
\hline Moderate & $8(42.1)$ & $2(10.5)$ & $9(47.4)$ & $19(100.0)$ \\
\hline Very bad & $16(38.1)$ & $15(35.7)$ & $11(26.2)$ & $42(100.0)$ \\
\hline Unbearable & $20(50.0)$ & $18(45.0)$ & $2(5.0)$ & $40(100.0)$ \\
\hline Total & $44(43.6)$ & $35(34.7)$ & $22(21.8)$ & $101(100.0)$ \\
\hline
\end{tabular}


to $90(89.1 \%)$ patients and the other $11(10.6 \%)$ patients received the second drug therapy. An antihypertensive drug was given as a second therapy in one of these patients because they had an increase in MAP. When the severity of headaches was checked at the $30^{\text {th }}$ minute, $5(5.0 \%)$ patients had no headache, $69(68.3 \%)$ patients had mild headache, $14(13.9 \%)$ patients had moderate level, 8 (7.9) patients had a very bad headache, and $5(5.0 \%)$ patients had excruciating headaches (Table 2). The decreases in the headache severity were divided into five levels as follows: $25(24.8 \%)$ patients' headache decreased 3 levels, 43 (42.6\%) patients' headache decreased 2 levels, and 23 (22.8\%) patients' headache decreased one level. Ten patients had no change in the severity of their headache (Table 3). When the MAP value of the patients at admission was $118.58 \pm 12.65 \mathrm{mmHg}$, after treatment the patients' MAP value at the $30^{\text {th }}$ minute was decreased to $98.41 \pm 13.43 \mathrm{mmHg}$. The rates of the decline in MAP values were found as $>30 \%$ for $13(12.9 \%)$ patients, $20.1-30 \%$ for $38(37.6 \%)$ patients, $10-20 \%$ for $30(29.7 \%)$ patients, <10\% for $16(14.9 \%)$ patients. Although MAP values of four patients were found to be increased, one remained the same (Table 4).
The decline in levels of headaches and MAP values of each decline level before and after treatment were calculated for patients with decline in headache after treatment. Whether there was a decline in MAP values after treatment was tested using these calculated values with the Wilcoxon signed-rank test. Although there was a statistically significant $(\mathrm{p}<0.001)$ decrease in the MAP rates of patients with a 2-3 level decrease in headache severity, there was no statistically significant $(\mathrm{p}>0.05)$ drop in the MAP rates of patients with a one level decrease in headache severity after treatment (Table 5). The comparison of decrease level in headache severity and MAP decline percentage after treatment is shown in Table 6.

Eleven patients who received the second therapy and 5 patients who did not agree to the second therapy were examined after 60 minutes and the decreases in headache and BP values were recorded. The severity of headache remained the same in one $(6.2 \%)$ patient, decreased one level in 1 (6.2\%), two levels in 9 $(56.2 \%), 3$ levels in $4(25.0 \%)$, and 4 levels in 1 (6.2\%) patient. For the same group of patients, the MAP value decreased from $107.29 \pm 17.25$ to $100.42 \pm 16.32 \mathrm{mmHg}$. The decline rates in

Table 2. The severity of headache at admission vs. the $30^{\text {th }}$ min after analgesia

The severity of headache $30^{\text {th }}$ min after analgesia

\begin{tabular}{lcccccc} 
& Absent & Weak & Moderate & Very bad & Unbearable \\
The severity of headache at admission & $\mathbf{n}(\%)$ & $\mathbf{n}(\%)$ & $\mathbf{n}(\%)$ & $\mathbf{n}(\%)$ & $\mathbf{n}(\%)$ & Total $(\%)$ \\
Moderate & $4(21.1)$ & $14(73.7)$ & $1(5.3)$ & - & - & $19(100.0)$ \\
Very bad & $1(2.4)$ & $33(78.6)$ & $4(9.5)$ & $4(9.5)$ & - & $42(100.0)$ \\
Unbearable & - & $22(55.0)$ & $9(22.5)$ & $4(10.0)$ & $5(12.5)$ & $40(100.0)$ \\
Total & $5(5.0)$ & $69(68.3)$ & $14(13.9)$ & $8(7.9)$ & $5(4.8)$ & $101(100.0)$ \\
\hline
\end{tabular}

Table 3. The severity of headache at the admission vs. decrease rates of headaches at the $30^{\text {th }}$ min after analgesia

The rate of decrease in the headache $30^{\text {th }} \mathrm{min}$

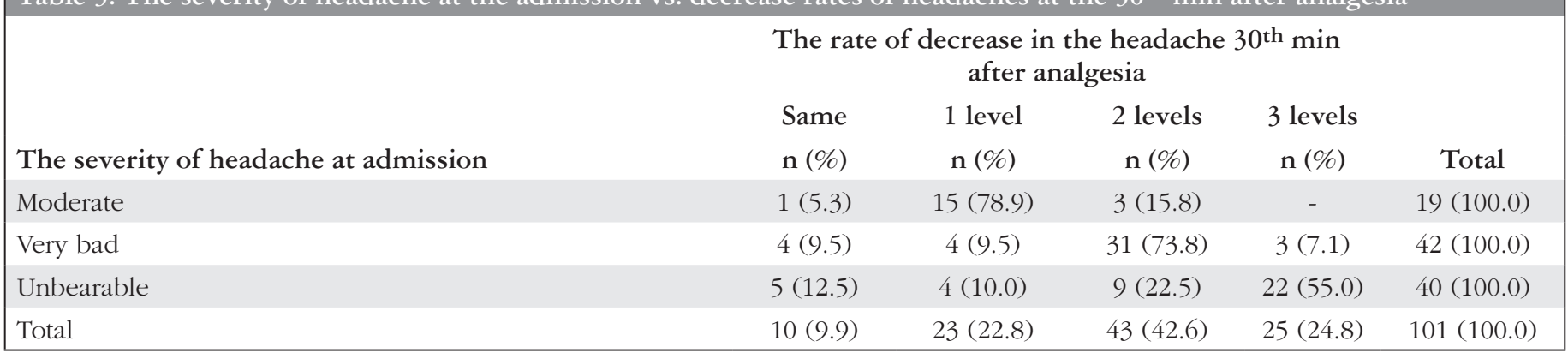

Table 4 . The severity of headache at the admission vs. decrease rates of mean arterial pressure values at the 30 th min after analgesia

\begin{tabular}{|c|c|c|c|c|c|c|c|}
\hline The severity of headache at admission & \multicolumn{7}{|c|}{ The rate of decrease in the MAP values at the $30^{\text {th }}$ min after analgesia } \\
\hline Moderate & $2(10.5)$ & $8(42.1)$ & $6(31.6)$ & $2(10.5)$ & - & $1(5.3)$ & $19(100.0)$ \\
\hline Very bad & $5(11.9)$ & $11(26.2)$ & $18(42.9)$ & $6(14.3)$ & $2(4.8)$ & - & $42(100.0)$ \\
\hline Unbearable & $8(20.0)$ & $11(27.5)$ & $14(35.0)$ & $5(12.5)$ & $2(5.0)$ & - & $40(100.0)$ \\
\hline
\end{tabular}


Table 5. The mean arterial pressure decrease levels before $(0 \mathrm{~min})$ and after $\left(30^{\text {th }} \mathrm{min}\right)$ analgesia

\begin{tabular}{|c|c|c|c|}
\hline Decrease level for headache & $\begin{array}{c}\text { MAP at } 0 \text { min } \\
\text { Median (min-max) }\end{array}$ & $\begin{array}{l}\text { MAP at } 30^{\text {th }} \min \\
\text { Median (min-max) }\end{array}$ & $\mathrm{p}^{*}$ \\
\hline Same & $112.0(100.7-123.0)$ & $106.7(83.3-115.3)$ & 0.384 \\
\hline One level & $115.3(92.7-143.3)$ & $96.7(80.0-146-7)$ & 0.059 \\
\hline Two levels & $116.3(104.7-160.0)$ & $96.7(73.3-123.6)$ & $<0.001$ \\
\hline Three levels & $120.0(103.3-163.3)$ & $96.7(73.3-130.0)$ & $<0.001$ \\
\hline
\end{tabular}

Table 6. The comparison of the decrease levels in the headache and decrease rates of mean arterial pressure at the 30 th min

\begin{tabular}{|lccccccc} 
& \multicolumn{3}{c}{ The rate of decrease in the MAP values $30^{\text {th }}$ min after analgesia } & Total \\
& $<10 \%$ & $10-20 \%$ & $20.1-30 \%$ & $>30 \%$ & Increase & Same \\
Decrease level for headache & $\mathbf{n}(\%)$ & $\mathbf{n}(\%)$ & $\mathbf{n}(\%)$ & $\mathbf{n}(\%)$ & $\mathbf{n}(\%)$ & $\mathbf{n}(\%)$ & - \\
Same & $4(40.0)$ & - & $3(30.0)$ & - & $3(30.0)$ & $10(100.0)$ \\
One level & $5(21.7)$ & $8(34.8)$ & $6(26.1)$ & $2(8.7)$ & $1(4.3)$ & $1(4.3)$ & $23(100.0)$ \\
Two levels & $5(11.6)$ & $13(30.2)$ & $17(39.5)$ & $8(18.6)$ & - & - & $43(100.0)$ \\
Three levels & $1(4.0)$ & $9(36.0)$ & $12(48.0)$ & $3(12.0)$ & - & - & $25(100.0)$ \\
Total & $15(14.9)$ & $30(29.7)$ & $38(37.6)$ & $13(12.9)$ & $4(4.0)$ & $1(1.0)$ & $101(100.0)$ \\
MAP: Mean arterial pressure & & & & & & & \\
\hline
\end{tabular}

MAP values were $<10 \%$ for $2(12.5 \%)$ patients, $<10-20 \%$ for 3 $(18.8 \%)$ patients, $<20.1-30 \%$ for $8(50.0 \%)$ patients, and $>30 \%$ for $1(6.2 \%)$ patient. MAP values were increased in $2(12.5 \%)$ patients.

\section{Discussion}

To the best of our knowledge, this is the first study to examine $\mathrm{BP}$ response for the headache therapy for the patients with primary headache accompanying HT in the emergency department. In this study, we identified that when the headache was treated, the accompanying HT was significantly decreased.

Headache and HT are two common causes of admission to the emergency department. However, these findings may be seen together. This combination occurs because HT is a frequent comorbid condition and acute headache leads to vascular sympathetic stimulation, which causes an increase in heart rate and BP (12). In the pathogenesis of vascular headache, in the earlier stage, there is a cerebral vasoconstriction that can reduce cerebral blood flow by $25 \%$ (13). Treating patients with HT who also have headache with antihypertensive drugs may cause cerebral perfusion that is already impaired to worsen, and this leads to a risk of ischemic stroke and cerebral cell loss $(14,15)$.

The disease groups with high prevalence accompanying migraine are angina, acute myocardial infarction, affective disorders (depression, mania, anxiety and panic disorder), and stroke (16). In a migraine attack accompanied by stroke, $\mathrm{BP}$ increases to maintain cerebral perfusion in the border line ischemic area. In these conditions, which may be considered as a headache caused by HT, if antihypertensive agents are used the infarct area may grow larger. In the same way, diuretics, which aim at reducing HT, may cause an increase in blood viscosity and hematocrit, which in turn cause a reduction in blood fluidity and an increase in the infarct area (17). In order to provide the correct treatment, hypertensive emergencies should be accurately diagnosed, and in order to avoid possible complications, physicians should be familiar with the pharmacologic and clinical effects of drugs used (18).

Ferreira et al. (19) conducted a survey with physicians regarding hypertensive emergencies. In this study, the response by $95.2 \%$ of 250 physicians was that headaches were the second alarm finding of hypertensive emergencies. However, mild (140$159 / 90 \mathrm{mmHg}$ to $99 \mathrm{mmHg}$ ) or moderate $(160-179 / 100 \mathrm{mmHg}$ to $109 \mathrm{mmHg}$ ) chronic arterial HT does not cause headaches, but headache can be observed as a result of severe and sudden fluctuations in BP (20). Headaches caused by HT are not an indicator of an end-organ damage, so immediate treatment for BP is not needed (21).

When clinical signs of acute organ damage findings, which are suggestive of hypertensive emergency are not apparent, and evaluation and follow-up of patients in the emergency department are not clear, these can mislead physicians in decisions (22). They may connect the headache to HT and treatments to reduce BP can be given to patients.

\section{Study Limitations}

Pain treatments were given because the patients were admitted for headaches and because they had the expectation for quick medication. The limitation of our study is that we had to give medication to these patients without being able to differentiate patients whose high BP would fall spontaneously without medication (e.g., caused by anxiety, HT related with the white coat effect). 


\section{Conclusion}

This study showed that in the primary headaches, which are often associated with HT, instead of treating high BP by considering secondary causes, when headache was treated, BP spontaneously decreased. We believe that detailed, multi-centered studies are need regarding patients with headaches accompanied by symptoms of high BP or admission because of high BP accompanied by headache

\section{Acknowledgements}

The investigators express their gratitude to Tuğba Akkaya Hocagil and Çağatay Büyükuysal for their statistical supervision.

\section{Ethics}

Ethics Committee Approval: The study was approved by the Dr. Lutfi Kirdar Kartal Training and Research Hospital of Local Ethics Committee (approval number: 8951337/1009/120).

Informed Consent: Consent form was filled out by all participants.

Peer-review: Externally peer-reviewed.

\section{Authorship Contributions}

Surgical and Medical Practices: A.C.H., H.H., Concept: A.C.H., H.H., Design: A.C.H., Data Collection or Processing: A.C.H., H.H., Analysis or Interpretation: H.H., V.Ü., Literature Search: A.C.H., H.H., V.Ü., Writing: A.C.H., H.H.

Conflict of Interest: No conflict of interest was declared by the authors.

Financial Disclosure: The authors declared that this study received no financial support.

\section{References}

1. Levy PD, Mahn JJ, Miller J, Shelby A, Brody A, Davidson R, Burla MJ, Marinica A, Carroll J, Purakal J, Flack JM, Welch RD. Blood pressure treatment and outcomes in hypertensive patients without acute target organ damage: a retrospective cohort. Am J Emerg Med 2015;33:1219-1224.

2. Friedman BW, Mistry B, West JR, Wolowitz A. The association between headache and elevated blood pressure among Patients presenting to an. Am J Emerg Med 2014;32:976-998.

3. Ezeala-Adikaibe BA, Onyekonwu C, Okudo G, Onodugo O, Ekenze S, Orjioke C, Chime P, Ezeanosike O, Mbadiwe N, Chikani M, Okwara C, Ulasi I, Ijoma U. Prevalence of primary headaches in an urban slum in Enugu South East Nigeria: a door-to-door survey. Headache 2014;54:1601-1610.

4. Woldeamanuel YW, Andreou AP, Cowan RP. Prevalence of migraine headache and its weight on neurological burden in Africa: A 43-year systematic review and meta-analysis of community-based studies. J Neurol Sci 2014;342:1-15.

5. Kwiatkowski T, Friedman BW. Headache Disorders. In: Marx JA, Hockberger RS, Wals RM. Eds. Rosen's Emergency Medicine, 8th ed. Philadelphia: Elsevier Saunders; 2014:1386-1397.

6. Stovner $\mathrm{Lj}$, Hagen $\mathrm{K}$, Jensen $\mathrm{R}$, Katsarava Z, Lipton $\mathrm{R}$, Scher A, Steiner T, Zwart JA. The global burden of headache: A documentation of headache prevalence and disability worldwide. Cephalalgia 2007;27:193-210.
7. Friedman BW, Hochberg ML, Esses D, Grosberg B, Corbo J, Toosi B, Meyer RH, Bijur PE, Lipton RB, Gallagher EJ. Applying the International Classification of Headache Disorders to the emergency department: an assessment of reproducibility and the frequency with which a unique diagnosis can be assigned to every acute headache presentation. Ann Emerg Med 2007;49:409-419.

8. Silberstein SD. Headache Management. In: Benzon HT, Rathmell JP, Wu CL, Turk DC, Argoff CE, Hurley R W. Practical Management of Pain, 5th ed. Philadelphia: Elsevier Saunders 2012:408-423.

9. Lloyd-Jones D, Adams RJ, Brown TM, Carnethon M, Dai S, De Simone G, Ferguson TB, Ford E, Furie K, Gillespie C, Go A, Greenlund K, Haase N, Hailpern S, Ho PM, Howard V, Kissela B, Kittner S, Lackland D, Lisabeth L, Marelli A, McDermott MM, Meigs J, Mozaffarian D, Mussolino M, Nichol G, Roger VL, Rosamond W, Sacco R, Sorlie P, Stafford R, Thom T, WasserthielSmoller S, Wong ND, Wylie-Rosett J; American Heart Association Statistics Committee and Stroke Statistics Subcommittee. Executive summary: heart disease and stroke statistics--2010 update: a report from the American Heart Association. Circulation 2010;121:948-954.

10. Baumann BM, Cline DM, Pimenta E. Treatment of hypertension in the emergency department. J Am Socf Hypertens 2011;5:366-377.

11. Tilman K, DeLashaw M, Lowe S, Springer S, Hundley S, Counselman FL. Recognizing asymptomatic elevated blood pressure in ED patients: how good (bad) are we? Am J Emerg Med 2007;25:313-317.

12. Hamner JW, Villamar MF, Fregni F, Taylor JA. Transcranial direct current stimulation (tDCS) and the cardiovascular responses to acute pain in humans. Clinical Neurophysiology 2015;126:1039-1046.

13. Annequin D, Tourniaire B, Massiou H. Migraine and headache in childhood and adolescence. Pediatr Clin North Am 2000;47:617-631.

14. Cherney D, Strauss S. Management of Patients with hypertensive urgencies and emergencies: a systematic review of the literature. J Gen Intern Med 2002;17:937-945

15. Kumar S, Bhatia T, Kapoor A. Hypertension emergencies and urgencies. Clinical Queries: Nephrology 2013;2;1-14.

16. Martin PR, Aiello R, Gilson K, Meadows G, Milgrom J, Reece J. Cognitive behavior therapy for comorbid migraine and/or tension-type headache and major depressive disorder: An exploratory randomized controlled trial. Behav Res Ther 2015;73:8-18.

17. Shih HM, Lin WC, Wang CH, Lin LC. Hypertensive Patients Using Thiazide Diuretics as Primary Stroke Prevention Make Better Functional Outcome after Ischemic Stroke. J Stroke Cerebrovasc Dis 2014;23:2414-2418.

18. Fenves AZ, Ram CV. Drug treatment of hypertensive urgencies and emergencies. Semin Nephrol 2005;25;272-280.

19. Ferreira D, Cunha J, Pina R, Santos F. Hypertensive emergencies and urgencies: Do all doctors look for the same clinical characteristics? Eurn J Intern Med 2013;24:33-34.

20. Assarzadegan F, Asadollahi M, Hesami O, Aryani O, Mansouri B, Moghadam NB. Secondary headaches attributed to arterial hypertension. Iran J Neurol 2013;12:106-110.

21. Levy PD. Hypertension. In: Marx JA, Hockberger RS, Wals RM, eds. Rosen's Emergency Medicine, 8th ed. Philadelphia: Elsevier Saunders, 2014:11131123.

22. Wolf SJ, Lo B, Shih RD, Smith MD, Fesmire FM; American College of Emergency Physicians Clinical Policies Committee. Clinical policy: critical issues in the evaluation and management of adult patients in the emergency department with asymptomatic elevated blood pressure. Ann Emerg Med 2013;62:59-68. 